\title{
Actions of Quercetin, a Polyphenol, on Blood Pressure
}

\author{
Yoshinori Marunaka 1,2,3,*, Rie Marunaka ${ }^{1,4}$, Hongxin Sun ${ }^{1}$, Toshiro Yamamoto ${ }^{4}$, \\ Narisato Kanamura ${ }^{4}$, Toshio Inui ${ }^{1,2,5}$ and Akiyuki Taruno ${ }^{1}$
}

1 Department of Molecular Cell Physiology, Kyoto Prefectural University of Medicine, Kyoto 602-8566, Japan; marurie@koto.kpu-m.ac.jp (R.M.); crystal@koto.kpu-m.ac.jp (H.S.); inui-cl@nike.eonet.ne.jp (T.I.); taruno@koto.kpu-m.ac.jp (A.T.)

2 Department of Bio-Ionomics, Kyoto Prefectural University of Medicine, Kyoto 602-8566, Japan

3 Japan Institute for Food Education and Health, St. Agnes' University, Kyoto 602-8013, Japan

4 Department of Dental Medicine, Kyoto Prefectural University of Medicine, Kyoto 602-8566, Japan; yamamoto@koto.kpu-m.ac.jp (T.Y.); kanamura@koto.kpu-m.ac.jp (N.K.)

5 Saisei Mirai Clinics, Moriguchi 570-0012, Japan

* Correspondence: marunaka@koto.kpu-m.ac.jp; Tel.: +81-75-251-5310

Academic Editor: Rosa M. Lamuela-Raventós

Received: 1 December 2016; Accepted: 24 January 2017; Published: 29 January 2017

\begin{abstract}
Disorder of blood pressure control causes serious diseases in the cardiovascular system. This review focuses on the anti-hypertensive action of quercetin, a flavonoid, which is one of the polyphenols characterized as the compounds containing large multiples of phenol structural units, by varying the values of various blood pressure regulatory factors, such as vascular compliance, peripheral vascular resistance, and total blood volume via anti-inflammatory and anti-oxidant actions. In addition to the anti-inflammatory and anti-oxidant actions of quercetin, we especially describe a novel mechanism of quercetin's action on the cytosolic $\mathrm{Cl}^{-}$concentration $\left(\left[\mathrm{Cl}^{-}\right]_{\mathrm{c}}\right)$ and novel roles of the cytosolic $\mathrm{Cl}^{-}$i.e., (1) quercetin elevates $\left[\mathrm{Cl}^{-}\right]_{\mathrm{c}}$ by activating $\mathrm{Na}^{+}-\mathrm{K}^{+}-2 \mathrm{Cl}^{-}$cotransporter 1 (NKCC1) in renal epithelial cells contributing to $\mathrm{Na}^{+}$reabsorption via the epithelial $\mathrm{Na}^{+}$channel $(\mathrm{ENaC}) ;(2)$ the quercetin-induced elevation of $\left[\mathrm{Cl}^{-}\right]_{\mathrm{c}}$ in renal epithelial cells diminishes expression of $\mathrm{ENaC}$ leading to a decrease in renal $\mathrm{Na}^{+}$reabsorption; and (3) this reduction of $\mathrm{ENaC}$-mediated $\mathrm{Na}^{+}$reabsorption in renal epithelial cells drops volume-dependent elevated blood pressure. In this review, we introduce novel, unique mechanisms of quercetin's anti-hypertensive action via activation of NKCC1 in detail.
\end{abstract}

Keywords: flavonoid; quercetin; $\mathrm{Na}^{+}-\mathrm{K}^{+}-2 \mathrm{Cl}^{-}$cotransporter 1; epithelial $\mathrm{Na}^{+}$channel; cytosolic $\mathrm{Cl}^{-}$concentration

\section{Introduction}

Blood pressure is regulated by many factors such as: (1) cardiac output, vascular compliance (reciprocal of elastance), and peripheral vascular resistance; (2) total blood volume dependent on body fluid volume; (3) nervous control systems (autonomic sympathetic and parasympathetic nervous systems, baroreflex and baroreceptors); and (4) renin-angiotensin system-regulating vascular resistance and renin-angiotensin-aldosterone system-regulating blood volume. Polyphenols containing large multiples of phenol structural units are widely distributed in plants, such as vegetables, soybeans, and fruits, and are well known to provide us with health benefits including anti-hypertensive actions via anti-inflammatory and anti-oxidant actions. Polyphenols show anti-inflammatory actions by inhibiting activity and/or production of inflammation-inducing enzymes such as cyclooxygenase [1-3], lipoxygenase [3,4] and TNF- $\alpha$ [1,5-8], etc. Polyphenols also have anti-oxidant abilities via interaction with anti-oxidant enzymes, such as heme oxygenase-1 (HO-1) [9], increases in the activities of various antioxidant enzymes, such as catalase and glutathione peroxidase [10], radical scavenging 
ability [10,11], and redox regulation by binding to $\beta$-actin, a cytoskeletal protein, and Keap1, a scaffold protein bound to the actin cytoskeleton controlling cytoprotective enzyme genes through sulfhydryl modification [12]. Thus, polyphenols protect vascular cells, including endothelial and smooth muscle cells, from inflammation and oxidative stress via these anti-inflammatory and anti-oxidant actions, and maintain normal vascular compliance and resistance, providing their anti-hypertensive actions.

In addition to these actions, growing evidence has demonstrated that polyphenols regulate ion transporters and channels $[13,14]$. It is generally accepted that ion environments regulated by ion transporters and channels are essentially important to maintain homeostasis of various cellular and body functions: e.g., blood pressure dependent on body fluid volume via regulation of epithelial $\mathrm{Na}^{+}$channels $(\mathrm{ENaC})[15,16]$, and hyperglycemia in insulin-resistant diabetes mellitus caused by low interstitial $\mathrm{pH}$ [17-21]. Quercetin activates $\mathrm{Na}^{+}-\mathrm{K}^{+}-2 \mathrm{Cl}^{-}$cotransporter 1 (NKCC1), leading to elevation of the cytosolic $\mathrm{Cl}^{-}$concentration $\left(\left[\mathrm{Cl}^{-}\right]_{c}\right)[22]$, which down-regulates gene expression of $\mathrm{ENaC}$ [23]. As a result of the aforementioned actions, polyphenols show various beneficial effects on body functions including regulation of blood pressure via diminution of vascular contraction [24] and renal $\mathrm{Na}^{+}$reabsorption by influencing ENaC gene expression $[15,23,25]$ and $\mathrm{Na}^{+}, \mathrm{K}^{+}$-ATPase activity [26]. This review will focus on the anti-hypertensive actions of quercetin (Figure 1) enriched in onion skins and ingested as a part of common diets [27], mainly via regulation of total blood volume dependent on body fluid volume, and also slightly through regulation of vascular compliance (reciprocal of elastance) and resistance.<smiles>O=c1c(O)c(-c2ccc(O)c(O)c2)oc2cc(O)cc(O)c12</smiles>

Quercetin (1)<smiles>O=c1c(OC2OC(CO)[C@@H](O)[C@H](O)[C@H]2O)c(-c2ccc(O)c(O)c2)oc2cc(O)cc(O)c12</smiles>

Quercetin glucoside (2)<smiles></smiles>

Sulfated quercetin (4)<smiles>O=C(O)[C@H]1O[C@@H](Oc2c(-c3ccc(O)c(O)c3)oc3cc(O)cc(O)c3c2=O)[C@H](O)[C@@H](O)[C@H]1O</smiles>

Glucuronidated quercetin (3)<smiles>COc1c(-c2ccc(O)c(O)c2)oc2cc(O)cc(O)c2c1=O</smiles>

Methylated quercetin (5)

Figure 1. Structures of quercetin (1) and its metabolites (2-5). 


\section{How Do We Take Up and Absorb Flavonoids into the Inside of the Body?}

Suzuki and Hara [28] have thoroughly summarized how humans absorb daily flavonoids, including quercetin. Therefore, in this review, we provide information on quercetin actions while avoiding information given by Suzuki and Hara [28]. Quercetin exists as such (aglycone) and in glycosylated forms (Figure 1). Quercetin aglycone is lipophilic, based on its structure (Figure 1). Due to this lipophilic property quercetin aglycone is easily absorbed through the phospholipid bilayer of intestinal mucosal epithelial cells [28]. On the other hand, the glycosylated form of quercetin is non-lipophilic and commonly found in plants, such as fruits, vegetables, and soybeans. This glycosylated form of quercetin is not easily absorbed into the body due to its non-lipophilic property. However, Day et al. have reported that lactase phlorizin hydrolase (LPH) expressed in the brush border membrane of the rat intestine hydrolyzes the glycosylated form of quercetin to the aglycone form [29]. Whereas quercetin aglycone is absorbed through the phospholipid bilayers of intestinal mucosal epithelial cells by diffusion, the monoglucoside form of quercetin is also absorbed into the cytosol of intestinal cells by sodium glucose transporter-1 (SGLT-1) expressed on the brush border membrane of rat intestine [30] and the apical membrane of human small intestinal model Caco-2 cells [31]. This monoglucoside-type of quercetin taken up into the cells is reported to be deglycosylated by $\beta$-glucosidase located in the cytosolic space of human intestinal cells [32]. Thus, quercetin molecules are taken up into the intestinal cells by simple diffusion through the phospholipid bilayer and by facilitated diffusion mediated via SGLT-1, and exist as aglycone in the cytosolic space in both cases of humans and rats. Then, in the cells the quercetin aglycone is glucuronidated, sulfated, or methylated (Figure 1) and these modified types of quercetin molecules enter circulation [33]. The major metabolites in rats are di- and tri-conjugates of quercetin, such as glucuronidated, sulfate and/or methylated ones [33,34], while in humans, quercetin-3'-O-glucuronide is the major circulating metabolite [34]. These observations suggest that significant species differences occur in major circulating metabolites of quercetin. Therefore, although rat is one of the good models, we should consider these specific differences in metabolites of quercetin in circulation to study the quercetin actions on body and cell functions.

\section{Actions of Quercetin on Blood Pressure in Human and Model Animals}

In humans, oral intake of quercetin of $150 \sim 730 \mathrm{mg} /$ day between four and ten weeks shows anti-hypertensive actions. A randomized, double-blind, placebo-controlled, crossover study indicates that $730 \mathrm{mg} /$ day quercetin intake for four weeks decreases systolic and diastolic blood pressures in stage 1 hypertensive patients, but has no effects on systolic or diastolic blood pressure with prehypertension [35]. A study in human with metabolic syndrome [36] has reported that $150 \mathrm{mg} /$ day quercetin intake for five weeks decreases systolic blood pressure. Further, a double-blind randomized clinical trial [37] carried out on 72 women with type 2 diabetes indicates that $500 \mathrm{mg} /$ day quercetin intake for 10 weeks significantly decreases systolic blood pressure, although diastolic pressure is not significantly affected by the quercetin intake. Serban et al. [38] summarize several human meta-analysis of randomized controlled trials, indicating that quercetin intake $>500 \mathrm{mg}$ /day over eight weeks, but not $\leq 500 \mathrm{mg} /$ day, significantly decreases systolic and diastolic blood pressures.

In model animals, oral administration of quercetin also shows an anti-hypertensive action $[15,16]$. Choi et al. [39] have reported direct actions of quercetin on vascular tension of the aorta obtained from renal hypertensive rats. In this ex vivo study [39], they have demonstrated that quercetin $\left(10^{-5} \mathrm{M}\right)$ acutely potentiates vascular relaxation induced by acetylcholine in $2 \mathrm{~K} 1 \mathrm{C}$ hypertensive rats, suggesting that quercetin shows its anti-hypertensive action by diminishing elastance of blood vessels. Galisteo et al. [40] have reported the action of chronic oral intake of quercetin on systolic blood pressure and vascular function in deoxycorticosterone acetate (DOCA)-salt hypertensive rats. Quercetin enhances endothelial-dependent aortic dilatations in rats developed with DOCA-salt-induced hypertension in a similar manner to verapamil, a $\mathrm{Ca}^{2+}$ channel blocker, which reduces blood pressure [40]. However, this study [40] indicates that quercetin is more effective in 
improving hypertension than verapamil in volume-expanded hypertension. This clearly indicates that, in addition to vascular relaxation, a decrease in body fluid volume is partly to account for the hypertensive action of quercetin. This action of quercetin could be mainly applied to reduce the elevated systolic blood pressure with age caused by a decrease in compliance of the aorta, although quercetin is also effective on volume-expanded hypertension. Further, quercetin shows an anti-hypertensive action in spontaneously hypertensive rats [41]. An in vivo study [42] in spontaneously hypertensive rats reports that quercetin increases the sensitivity of the parasympathetic component of the baroreflex, decreasing the mean artery pressure. Further, quercetin has been reported to attenuate the noradrenaline-induced contraction in a perfused mesenteric resistance vascular bed isolated from spontaneously hypertensive rats [43]. Quercetin also interrupts the renin-angiotensin system via diminution of mRNA expression of angiotensin-converting enzyme (ACE) and inhibition of ACE activity [44]. A study [45] performed in $\mathrm{NaCl}$-induced volume-expanded hypertensive rats indicates that quercetin intake of 50,100, and $150 \mathrm{mg} / \mathrm{kg} /$ day decreases systolic and diastolic pressures in a dose-dependent manner, supporting that quercetin has an anti-hypertensive action in volume-expanded hypertension. Thus, quercetin shows its anti-hypertensive actions via regulation of vascular compliance (the reciprocal of elastance) and resistance, total blood volume dependent on body fluid volume, autonomic nervous system, and the renin-angiotensin system.

\section{Anti-Inflammatory and Anti-Oxidant Actions of Quercetin and Its Influence on Blood Pressure}

Quercetin has been reported to have an anti-inflammatory action in both human and model animals by inhibiting activities of cyclooxygenase [1-3], lipoxygenase [3,4], expression of cyclooxygenase and production of $\mathrm{PGE}_{2}$ [2], diminishing production of interleukin (IL) $-1 \alpha$ [7], PKC-dependent IgE-mediated proinflammatory mediator, IL-6 and IL-8 [8], TNF- $\alpha$ [1,5-8], and poly (ADP-ribose) polymerase-1 (PARP-1) [46], down-regulating vascular cell adhesion molecule-1 (VCAM-1) and cluster differentiation (CD) 80 [47], etc. Quercetin also shows anti-oxidant actions via radical scavenging ability [48] and by interacting with anti-oxidant enzymes, such as heme oxygenase-1 (HO-1), which protects oxidative stress $\mathrm{H}_{2} \mathrm{O}_{2}$-induced apoptosis, and reduces intracellular ROS production and mitochondria dysfunction [9]. Thus, quercetin shows its anti-hypertensive actions $[35,49]$ via possible mechanisms dependent on the anti-inflammatory and anti-oxidant actions, such as protection of cardiovascular cells associated with a decrease in triacylglycerol concentration and an increase in HDL-cholesterol concentration [50], endothelium-dependent vasodilation due to an increased NO production [51], and prevention of endothelial cell apoptosis [52], etc. Due to the anti-hypertensive effect of quercetin via vascular resistance has already been extensively discussed in many review articles [53-57]. In the following sections we will focus on mechanisms of the anti-hypertensive action of quercetin via control of body fluid volume by altering the intracellular ion environments.

\section{Roles of ENaC in Control of Blood Pressure}

Salt-sensitive hypertension is caused by an expansion of body fluid volume via an increase of water absorption due to high salt intake-induced elevation of body fluid osmolarity. Dahl salt-sensitive hypertensive rats are commonly used to study the molecular mechanism of salt-sensitive hypertension. Quercetin action on salt-sensitive hypertension has been studied in this animal model. High salt intake causes hypertension in Dahl salt-sensitive hypertensive rats (Figure 2) [15]. Daily oral intake of $10 \mathrm{mg} / \mathrm{kg}$ of quercetin significantly suppresses the high salt intake-induced elevation of the systolic blood pressure in Dahl salt-sensitive hypertensive rats (Figure 2), and shows a tendency to increase urine volume and $\mathrm{NaCl}$ excretion into urine with no effects on the plasma aldosterone level $[15,58,59]$. This oral administration of quercetin diminishes mRNA expression of the pore-forming $\alpha$ subunit of $\mathrm{ENaC}$ (Figure 3) [15], essentially regulating the amount of $\mathrm{Na}^{+}$reabsorption in the kidney, which is a key regulator of blood pressure via determination of body fluid volume $[16,60]$. Namely, the activity 
of individual $\mathrm{ENaC}$, and the number of $\mathrm{ENaC}$ expressed at the apical membrane of renal collecting ducts, critically control blood pressure [61-63].

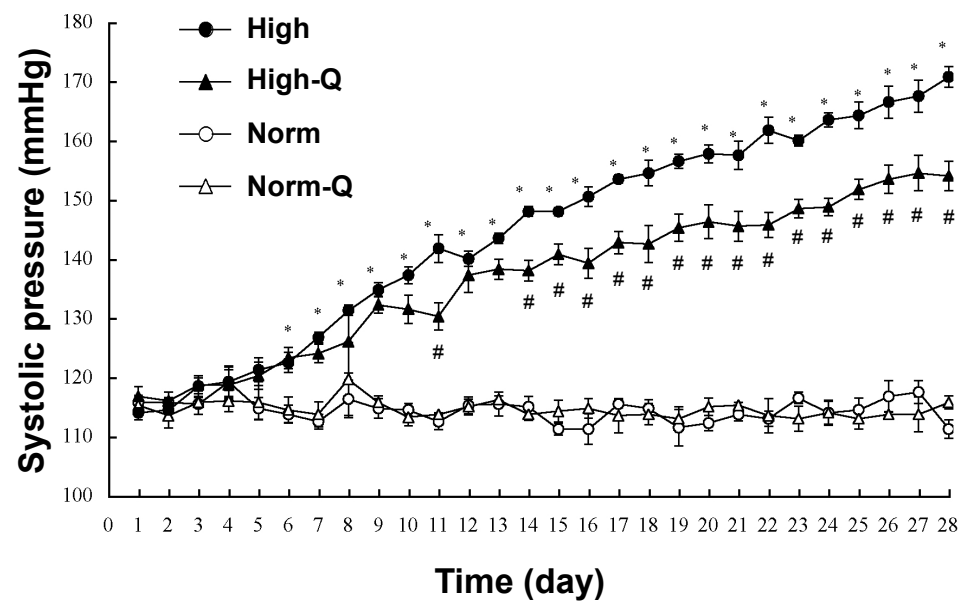

Figure 2. Systolic arterial pressure of Dahl salt-sensitive hypertensive rats. The systolic arterial pressure is represented as means $\pm \mathrm{SEM}$ ( $n=4$ in each group). Norm: normal diet; Norm-Q: normal diet with quercetin; High: high-NaCl diet; and High-Q: high- $\mathrm{NaCl}$ diet with quercetin. * Significant difference between high- $\mathrm{NaCl}$ diet (High) and normal diet (Norm) at the same experimental time $(p<0.05)$. \# Significant difference between high- $\mathrm{NaCl}$ with quercetin (High-Q) and high- $\mathrm{NaCl}$ diet (High) at the same experimental time $(p<0.05)$. Quercetin $(10 \mathrm{mg} / \mathrm{kg} /$ day $)$ was orally applied. The systolic blood pressure, which was measured under an awaking condition by the tail cuff method. Adopted from [15] with allowance for non-profit use of the figure.

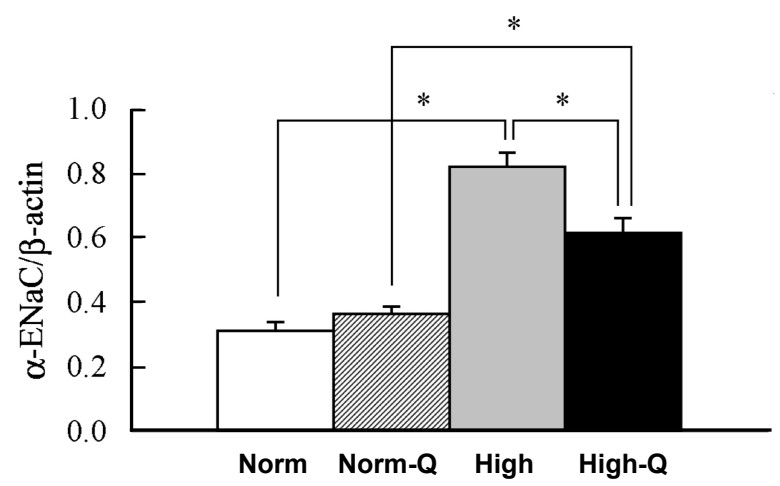

Figure 3. mRNA expression of $\alpha \mathrm{ENaC}$ in the kidney of Dahl salt-sensitive hypertension rats. The amount of mRNA expression of $\alpha \mathrm{ENaC}$ is expressed as the ratio to $\beta$-actin expression. Data are represented as means \pm SEM obtained from four rats. Norm: normal diet; Norm-Q: normal diet with quercetin; High: high- $\mathrm{NaCl}$ diet and High-Q: high- $\mathrm{NaCl}$ diet with quercetin. * Significant difference at the level of $p<0.05$. Quercetin (10 mg/ kg/day) was orally applied. Adopted from [15] with allowance for non-profit use of the figure.

Canessa et al., in Rossier's research group, have cloned $\mathrm{ENaC}$ subunits from rat colon $[64,65]$ : in 1993, they cloned the pore-forming $\alpha$ subunit of $\mathrm{ENaC}$ and in 1994 they cloned two other essential subunits, establishing that ENaC consists of three subunits, $\alpha, \beta$, and $\gamma$ [65]. Later, the $\delta$ subunit was also discovered in humans [66]. Patients with Liddle's syndrome, an autosomal dominant form of hereditary hypertension, carry gain-of-function mutations in $\mathrm{ENaC}$ genes, which disrupt ubiquitination sites of the channel. The deficiency of ubiquitination causes a constitutively increased number of ENaCs located in the apical membrane of the collecting duct epithelial cell of the kidney [67-76], leading to constitutively high $\mathrm{ENaC}-$ mediated renal $\mathrm{Na}^{+}$reabsorption and, thereby elevated body 
fluid volume. The phenomenon observed in Liddle's syndrome strongly indicates that the expression of ENaCs plays an essential role in control of blood pressure. In Dahl salt-sensitive hypertensive rats, high salt intake elevates blood pressure associated with an increase in $\alpha \mathrm{ENaC}$ expression (Figure 3) abnormally responding to aldosterone [15], the plasma level of which is significantly lowered by high salt intake via the renin-angiotensin-aldosterone system [15]. This suggests that the increase in $\mathrm{ENaC}$ expression induced by high salt intake would elevate blood pressure due to the expansion of blood volume resulting from the elevation of body fluid volume caused by an increase in renal $\mathrm{Na}^{+}$reabsorption even with a low plasma aldosterone level due to high salt intake. This means that high salt-sensitive hypertension would be due to disorders in the regulation of ENaC expression by aldosterone [58]. Orally administered quercetin of $10 \mathrm{mg} / \mathrm{kg} /$ day significantly diminishes the elevated $\alpha \mathrm{ENaC}$ expression under a low aldosterone condition caused by high salt intake in Dahl salt-sensitive hypertensive rats, while no effects are seen in control rats (Figure 3) [15]. In an in vitro experiment using a renal epithelial cell line, the quercetin action on ENaC expression has been studied [23], indicating that quercetin diminishes $\mathrm{ENaC}$ gene expression. This indicates that quercetin would be a useful compound showing an anti-hypertensive action on high salt-sensitive hypertension without any significant influence on the basal blood pressure in normotensive individuals with normal salt intake, although the quercetin action on ENaC expression should be further examined in various systems.

\section{Anti-Hypertensive Action of Quercetin via Down-Regulation of ENaC Expression Dependent on Elevation of $\left[\mathrm{Cl}^{-}\right]_{\mathrm{c}}$ Due to Its Stimulatory Action on NKCC-1}

In this section, we introduce the quercetin action on ENaC expression via stimulation of NKCC1, which regulates transepithelial $\mathrm{Cl}^{-}$secretion and $\left[\mathrm{Cl}^{-}\right]_{\mathrm{c}}$ by participating in $\mathrm{Cl}^{-}$uptake in epithelial cells [77]. Quercetin has been reported to stimulate NKCC1 (Figure 4) expressed in neural cells, which mediates uptake of $\mathrm{Cl}^{-}$into the cytosolic space driven by the $\mathrm{Na}^{+}, \mathrm{K}^{+}$-ATPase-generated electro-chemical potential of $\mathrm{Na}^{+}$[22,78-80]. The stimulatory action of quercetin on NKCC1 has been also reported in renal epithelial cells [14,25,81]. Although cAMP is indicated to act as a second messenger of quercetin action [82] and quercetin stimulates translocation of an unknown factor elevating NKCC1 activity to the basolateral membrane expressing NKCC1 [80], we still have little information on how quercetin stimulates NKCC1 at the molecular level. One possible molecular pathway of the quercetin action is mediated through sulfhydryl modification, as mentioned above [12]. Nevertheless, it is notable that quercetin modifies cellular functions via the elevation of $\left[\mathrm{Cl}^{-}\right]_{\mathrm{C}}$ by stimulating NKCC1 [22], whereas many studies indicate that quercetin influences various cellular and body functions via its anti-inflammatory and anti-oxidant actions, as mentioned above.

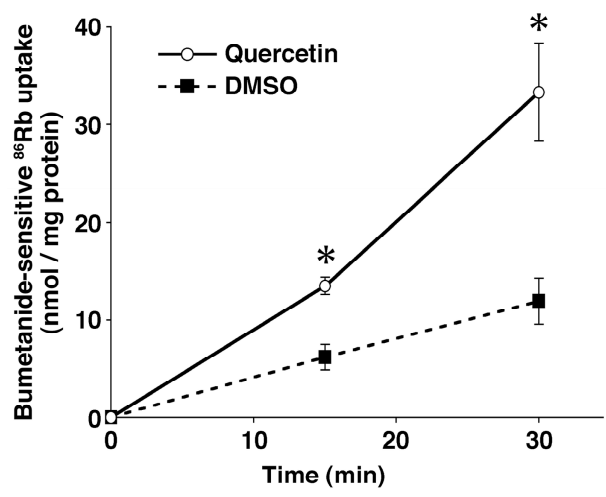

Figure 4. Effect of quercetin $(10 \mu \mathrm{M})$ on NKCC1 activity in rat pheochromocytoma PC12 cells. NKCC1 activity was estimated by measuring the bumetanide-sensitive ${ }^{86} \mathrm{Rb}$ uptake. Data are represented as means \pm SEM. ${ }^{*} p<0.01$ vs. DMSO. $n=3$ for $\mathrm{t}=0 \mathrm{~min}, n=5$ for $\mathrm{t}=15 \mathrm{~min}, n=7$ for $\mathrm{t}=30 \mathrm{~min}$. This observation indicates that quercetin stimulates activity of NKCC1. Adopted from [22] with allowance for non-profit use of the figure. 
Interestingly, it has been reported that reduction of $\left[\mathrm{Cl}^{-}\right]_{\mathrm{c}}$ up-regulates ENaC expression [23], while elevation of $\left[\mathrm{Cl}^{-}\right]_{\mathrm{c}}$ down-regulates ENaC expression [23]. Quercetin elevates $\left[\mathrm{Cl}^{-}\right]_{\mathrm{c}}$ by stimulating NKCC1 (Figure 4) [14,22], indicating that the quercetin-induced down-regulation of ENaC expression (Figure 3) would be mediated through elevation of $\left[\mathrm{Cl}^{-}\right]_{\mathrm{C}}$ [23]. This is supported by an observation that expression of $\mathrm{ENaC}$ is also down-regulated by a $\mathrm{Cl}^{-}$channel blocker, 5-nitro-2-(3-phenylpropylamino)benzoic acid (NPPB), which increases $\left[\mathrm{Cl}^{-}\right]_{\mathrm{c}}$ by blocking $\mathrm{Cl}^{-}$release from the cytosolic space via $\mathrm{Cl}^{-}$channels [23]. The quercetin-induced reduction of ENaC expression diminishes the amount of ENaC-mediated $\mathrm{Na}^{+}$reabsorption in epithelial cells of renal collecting ducts and lowers high salt intake-induced high blood pressure by compensating (reducing) elevated body fluid volume $[15,23]$. Although this unique action of quercetin on ENaC expression is interesting, we should further investigate the molecular mechanism of the quercetin action on ENaC expression in various systems. The investigation on the quercetin regulation of $\mathrm{ENaC}$ expression via control of $\left[\mathrm{Cl}^{-}\right]_{\mathrm{C}}$ mediated through NKCC1 would lead us to an interesting, novel therapy against hypertension.

\section{Conclusions}

Quercetin shows its anti-hypertensive actions via modification of various factors controlling blood pressure, such as vascular compliance (reciprocal of elastance) and resistance, total blood volume dependent on body fluid volume, autonomic nervous system, and renin-angiotensin-system via anti-inflammatory and anti-oxidative abilities. In addition to these abilities, quercetin has a unique action on regulation of ENaC gene expression. This action is mediated via control of $\left[\mathrm{Cl}^{-}\right]_{\mathrm{c}}$ by activating NKCC1. In this review, we show the novel idea on the role of "cytosolic $\mathrm{Cl}^{- \text {" }}$ in the anti-hypertensive action of quercetin on volume-dependent regulation of blood pressure. This novel idea regarding the anti-hypertensive action of quercetin via NKCC1 stimulation on ENaC-mediated $\mathrm{Na}^{+}$reabsorption in the kidney is summarized in Figure 5.

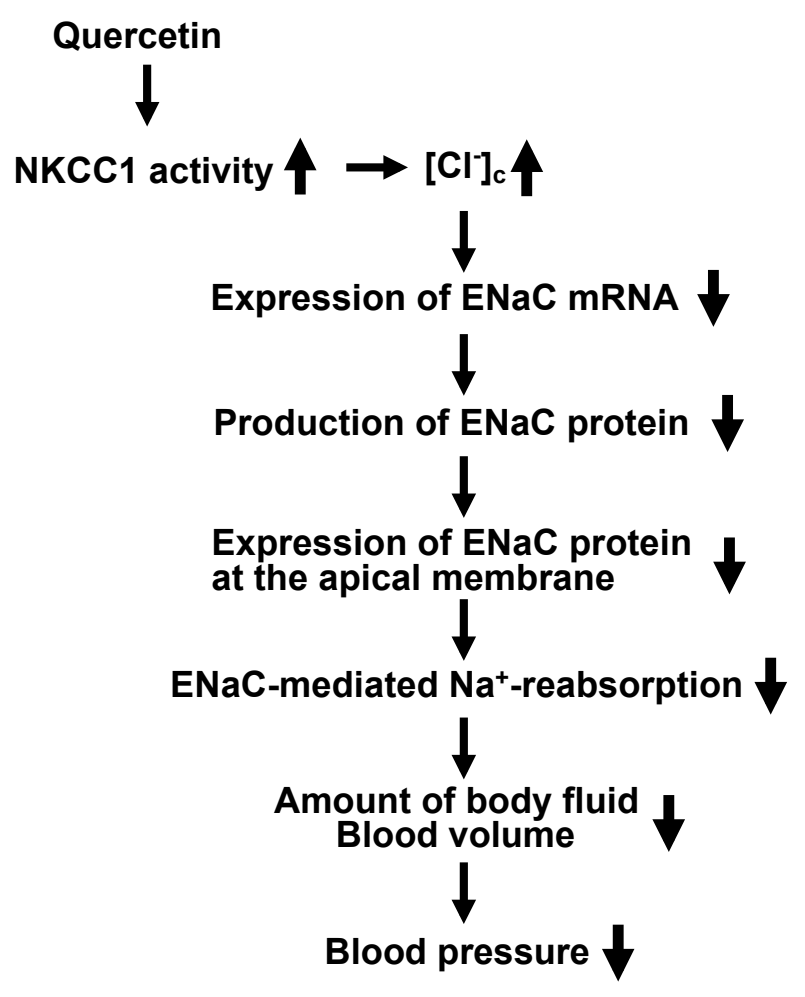

Figure 5. A possible mechanism of quercetin actions on blood pressure via modification of extracellular fluid volume mediated by ENaC-mediated $\mathrm{Na}^{+}$reabsorption in the kidney. 
Acknowledgments: This work was supported by Grants-in-Aid from Japan Society of the Promotion of Science (JSPS KAKENHI Grant Numbers JP25670111 and JP15K15034 to Y.M., JP16K18991 to H.S., and JP26713008 and JP16K15181 to A.T.), Salt Science (1235 to Y.M., 1429 and 1542 to A.T.), KIT-KPUM-KPU-KPhU Collaborative Research Grant (2013 and 2015) to Y.M., Society for Research on Umami Taste, Nestlé Nutrition Council, Japan to A.T., Kyoto Prefectural Public University Corporation to A.T., Kyoto-Funding for Innovation in Health-related R\&D Fields to Y.M., Fuji Foundation for Protein Research to Y.M., and Cell Research Conference to Y.M.

Conflicts of Interest: The authors declare no conflict of interest.

\section{Abbreviations}

The following abbreviations are used in this manuscript:

$\begin{array}{ll}\text { ACE } & \begin{array}{l}\text { angiotensin-converting enzyme } \\ \text { cluster differentiation }\end{array} \\ {\left[\mathrm{Cl}^{-}\right]_{\mathrm{c}}} & \begin{array}{l}\text { cytosolic } \mathrm{Cl}^{-} \text {concentration } \\ \text { DOCA }\end{array} \\ \text { ENaC } & \begin{array}{l}\text { epithelial } \mathrm{Na}^{+} \text {channel } \\ \text { heme oxygenase-1 }\end{array} \\ \mathrm{HO}-1 & \text { interleukin } \\ \text { IL } & \text { lactase phlorizin hydrolase } \\ \text { LPH } & \mathrm{Na}^{+}-\mathrm{K}^{+}-2 \mathrm{Cl}^{-} \text {cotransporter 1 } \\ \text { NKCC1 } & \text { (5-nitro-2-(3-phenylpropylamino)benzoic acid } \\ \text { NPPB } & \text { poly (ADP-ribose) polymerase-1 } \\ \text { PARP-1 } & \text { sodium glucose transporter-1 } \\ \text { SGLT-1 } & \text { sodium } \\ \text { VCAM-1 } & \text { vascular cell adhesion molecule-1 }\end{array}$

\section{References}

1. Endale, M.; Park, S.C.; Kim, S.; Kim, S.H.; Yang, Y.; Cho, J.Y.; Rhee, M.H. Quercetin disrupts tyrosine-phosphorylated phosphatidylinositol 3-kinase and myeloid differentiation factor-88 association, and inhibits MAPK/AP-1 and IKK/NF-KB-induced inflammatory mediators production in RAW 264.7 cells. Immunobiology 2013, 218, 1452-1467. [CrossRef] [PubMed]

2. Lee, K.M.; Hwang, M.K.; Lee, D.E.; Lee, K.W.; Lee, H.J. Protective effect of quercetin against arsenite-induced COX-2 expression by targeting PI3K in rat liver epithelial cells. J. Agric. Food Chem. 2010, 58, 5815-5820. [CrossRef] [PubMed]

3. Kim, H.P.; Mani, I.; Iversen, L.; Ziboh, V.A. Effects of naturally-occurring flavonoids and biflavonoids on epidermal cyclooxygenase and lipoxygenase from guinea-pigs. Prostaglandins Leukot. Essent. Fat. Acids 1998, 58, 17-24. [CrossRef]

4. Mlcek, J.; Jurikova, T.; Skrovankova, S.; Sochor, J. Quercetin and its anti-allergic immune response. Molecules 2016, 21. [CrossRef] [PubMed]

5. Mahmoud, M.F.; Hassan, N.A.; El Bassossy, H.M.; Fahmy, A. Quercetin protects against diabetes-induced exaggerated vasoconstriction in rats: Effect on low grade inflammation. PLoS ONE 2013, 8, e63784. [CrossRef] [PubMed]

6. Manjeet, K.R.; Ghosh, B. Quercetin inhibits LPS-induced nitric oxide and tumor necrosis factor- $\alpha$ production in murine macrophages. Int. J. Immunopharmacol. 1999, 21, 435-443.

7. Bureau, G.; Longpre, F.; Martinoli, M.G. Resveratrol and quercetin, two natural polyphenols, reduce apoptotic neuronal cell death induced by neuroinflammation. J. Neurosci. Res. 2008, 86, 403-410. [CrossRef] [PubMed]

8. Kempuraj, D.; Madhappan, B.; Christodoulou, S.; Boucher, W.; Cao, J.; Papadopoulou, N.; Cetrulo, C.L.; Theoharides, T.C. Flavonols inhibit proinflammatory mediator release, intracellular calcium ion levels and protein kinase C theta phosphorylation in human mast cells. Br. J. Pharmacol. 2005, 145, 934-944. [CrossRef] [PubMed]

9. Chow, J.M.; Shen, S.C.; Huan, S.K.; Lin, H.Y.; Chen, Y.C. Quercetin, but not rutin and quercitrin, prevention of $\mathrm{H}_{2} \mathrm{O}_{2}$-induced apoptosis via anti-oxidant activity and heme oxygenase 1 gene expression in macrophages. Biochem. Pharmacol. 2005, 69, 1839-1851. [CrossRef] [PubMed]

10. Bai, Y.; Xia, B.; Xie, W.; Zhou, Y.; Xie, J.; Li, H.; Liao, D.; Lin, L.; Li, C. Phytochemistry and pharmacological activities of the genus Prunella. Food Chem. 2016, 204, 483-496. [CrossRef] [PubMed] 
11. Tipoe, G.L.; Leung, T.M.; Hung, M.W.; Fung, M.L. Green tea polyphenols as an anti-oxidant and anti-inflammatory agent for cardiovascular protection. Cardiovasc. Hematol. Disord. Drug Targets 2007, 7, 135-144. [CrossRef] [PubMed]

12. Ishii, T.; Ishikawa, M.; Miyoshi, N.; Yasunaga, M.; Akagawa, M.; Uchida, K.; Nakamura, Y. Catechol type polyphenol is a potential modifier of protein sulfhydryls: development and application of a new probe for understanding the dietary polyphenol actions. Chem. Res. Toxicol. 2009, 22, 1689-1698. [CrossRef] [PubMed]

13. Sun, H.; Niisato, N.; Inui, T.; Marunaka, Y. Insulin is involved in transcriptional regulation of NKCC and the CFTR $\mathrm{Cl}^{-}$channel through PI3K activation and ERK inactivation in renal epithelial cells. J. Physiol. Sci. 2014, 64, 433-443. [CrossRef] [PubMed]

14. Sun, H.; Niisato, N.; Nishio, K.; Hamilton, K.L.; Marunaka, Y. Distinct action of flavonoids, myricetin and quercetin, on epithelial $\mathrm{Cl}^{-}$secretion: useful tools as regulators of $\mathrm{Cl}^{-}$secretion. BioMed Res. Int. 2014, 2014, 902735. [CrossRef] [PubMed]

15. Aoi, W.; Niisato, N.; Miyazaki, H.; Marunaka, Y. Flavonoid-induced reduction of ENaC expression in the kidney of Dahl salt-sensitive hypertensive rat. Biochem. Biophys. Res. Commun. 2004, 315, 892-896. [CrossRef] [PubMed]

16. Marunaka, Y. Characteristics and pharmacological regulation of epithelial $\mathrm{Na}^{+}$channel (ENaC) and epithelial $\mathrm{Na}^{+}$transport. J. Pharmacol. Sci. 2014, 126, 21-36. [CrossRef] [PubMed]

17. Aoi, W.; Hosogi, S.; Niisato, N.; Yokoyama, N.; Hayata, H.; Miyazaki, H.; Kusuzaki, K.; Fukuda, T.; Fukui, M.; Nakamura, N.; et al. Improvement of insulin resistance, blood pressure and interstitial $\mathrm{pH}$ in early developmental stage of insulin resistance in OLETF rats by intake of propolis extracts. Biochem. Biophys. Res. Commun. 2013, 432, 650-653. [CrossRef] [PubMed]

18. Hayata, H.; Miyazaki, H.; Niisato, N.; Yokoyama, N.; Marunaka, Y. Lowered extracellular pH is involved in the pathogenesis of skeletal muscle insulin resistance. Biochem. Biophys. Res. Commun. 2014, 445, 170-174. [CrossRef] [PubMed]

19. Marunaka, Y.; Yoshimoto, K.; Aoi, W.; Hosogi, S.; Ikegaya, H. Low pH of interstitial fluid around hippocampus of the brain in diabetic OLETF rats. Mol. Cell Therapies 2014, 2, 6. [CrossRef] [PubMed]

20. Aoi, W.; Marunaka, Y. The importance of regulation of body fluid $\mathrm{pH}$ in the development and progression of metabolic diseases. In Advances in Medicine and Biology; Berhardt, L.V., Ed.; Nova Publishers: Hauppauge, NY, USA, 2014; Volume 77, pp. 177-189.

21. Aoi, W.; Marunaka, Y. Importance of $\mathrm{pH}$ homeostasis in metabolic health and diseases: crucial role of membrane proton transport. BioMed Res. Int. 2014, 2014, 598986. [CrossRef] [PubMed]

22. Nakajima, K.; Niisato, N.; Marunaka, Y. Quercetin stimulates NGF-induced neurite outgrowth in PC12 cells via activation of $\mathrm{Na}^{+} / \mathrm{K}^{+} / 2 \mathrm{Cl}^{-}$cotransporter. Cell. Physiol. Biochem. 2011, 28, 147-156. [CrossRef] [PubMed]

23. Niisato, N.; Eaton, D.C.; Marunaka, Y. Involvement of cytosolic $\mathrm{Cl}^{-}$in osmoregulation of $\alpha$-ENaC gene expression. Am. J. Physiol. Renal Physiol. 2004, 287, F932-F939. [CrossRef] [PubMed]

24. Jeon, S.B.; Kim, G.; Kim, J.I.; Seok, Y.M.; Kim, S.H.; Suk, K.; Shin, H.M.; Lee, Y.H.; Kim, I.K. Flavone inhibits vascular contraction by decreasing phosphorylation of the myosin phosphatase target subunit. Clin. Exp. Pharmacol. Physiol. 2007, 34, 1116-1120. [CrossRef] [PubMed]

25. Fujimoto, S.; Niisato, N.; Sugimoto, T.; Marunaka, Y. Quercetin and NPPB-induced diminution of aldosterone action on $\mathrm{Na}^{+}$absorption and ENaC expression in renal epithelium. Biochem. Biophys. Res. Commun. 2005, 336, 401-407. [CrossRef] [PubMed]

26. Mezesova, L.; Bartekova, M.; Javorkova, V.; Vlkovicova, J.; Breier, A.; Vrbjar, N. Effect of quercetin on kinetic properties of renal Na,K-ATPase in normotensive and hypertensive rats. J. Physiol. Pharmacol. 2010, 61, 593-598. [PubMed]

27. D'Andrea, G. Quercetin: A flavonol with multifaceted therapeutic applications? Fitoterapia 2015, 106, $256-271$. [CrossRef] [PubMed]

28. Suzuki, T.; Hara, H. Role of flavonoids in intestinal tight junction regulation. J. Nutr. Biochem. 2011, 22, 401-408. [CrossRef] [PubMed]

29. Day, A.J.; Canada, F.J.; Diaz, J.C.; Kroon, P.A.; McLauchlan, R.; Faulds, C.B.; Plumb, G.W.; Morgan, M.R.; Williamson, G. Dietary flavonoid and isoflavone glycosides are hydrolysed by the lactase site of lactase phlorizin hydrolase. FEBS Lett. 2000, 468, 166-170. [CrossRef]

30. Wolffram, S.; Block, M.; Ader, P. Quercetin-3-glucoside is transported by the glucose carrier SGLT1 across the brush border membrane of rat small intestine. J. Nutr. 2002, 132, 630-635. [PubMed] 
31. Walgren, R.A.; Lin, J.T.; Kinne, R.K.; Walle, T. Cellular uptake of dietary flavonoid quercetin $4^{\prime}$ - $\beta$-glucoside by sodium-dependent glucose transporter SGLT1. J. Pharmacol. Exp. Ther. 2000, 294, 837-843. [PubMed]

32. Nemeth, K.; Plumb, G.W.; Berrin, J.G.; Juge, N.; Jacob, R.; Naim, H.Y.; Williamson, G.; Swallow, D.M.; Kroon, P.A. Deglycosylation by small intestinal epithelial cell $\beta$-glucosidases is a critical step in the absorption and metabolism of dietary flavonoid glycosides in humans. Eur. J. Nutr. 2003, 42, 29-42. [CrossRef] [PubMed]

33. Crespy, V.; Morand, C.; Manach, C.; Besson, C.; Demigne, C.; Remesy, C. Part of quercetin absorbed in the small intestine is conjugated and further secreted in the intestinal lumen. Am. J. Physiol. Gastrointest. Liver Physiol. 1999, 277, G120-G126.

34. Boonpawa, R.; Moradi, N.; Spenkelink, A.; Rietjens, I.M.; Punt, A. Use of physiologically based kinetic (PBK) modeling to study interindividual human variation and species differences in plasma concentrations of quercetin and its metabolites. Biochem. Pharmacol. 2015, 98, 690-702. [CrossRef] [PubMed]

35. Edwards, R.L.; Lyon, T.; Litwin, S.E.; Rabovsky, A.; Symons, J.D.; Jalili, T. Quercetin reduces blood pressure in hypertensive subjects. J. Nutr. 2007, 137, 2405-2411. [PubMed]

36. Egert, S.; Bosy-Westphal, A.; Seiberl, J.; Kurbitz, C.; Settler, U.; Plachta-Danielzik, S.; Wagner, A.E.; Frank, J.; Schrezenmeir, J.; Rimbach, G.; et al. Quercetin reduces systolic blood pressure and plasma oxidised low-density lipoprotein concentrations in overweight subjects with a high-cardiovascular disease risk phenotype: A double-blinded, placebo-controlled cross-over study. Br. J. Nutr. 2009, 102, 1065-1074. [CrossRef] [PubMed]

37. Zahedi, M.; Ghiasvand, R.; Feizi, A.; Asgari, G.; Darvish, L. Does quercetin improve cardiovascular risk factors and inflammatory biomarkers in women with type 2 diabetes: A double-blind randomized controlled clinical trial. Int. J. Prev. Med. 2013, 4, 777-785. [PubMed]

38. Serban, M.C.; Sahebkar, A.; Zanchetti, A.; Mikhailidis, D.P.; Howard, G.; Antal, D.; Andrica, F.; Ahmed, A.; Aronow, W.S.; Muntner, P.; et al. Effects of quercetin on blood pressure: A systematic review and meta-analysis of randomized controlled trials. J. Am. Heart Assoc. 2016, 5, e002713. [CrossRef] [PubMed]

39. Choi, S.; Ryu, K.H.; Park, S.H.; Jun, J.Y.; Shin, B.C.; Chung, J.H.; Yeum, C.H. Direct vascular actions of quercetin in aorta from renal hypertensive rats. Kidney Res. Clin. Pract. 2016, 35, 15-21. [CrossRef] [PubMed]

40. Galisteo, M.; Garcia-Saura, M.F.; Jimenez, R.; Villar, I.C.; Wangensteen, R.; Zarzuelo, A.; Vargas, F.; Duarte, J. Effects of quercetin treatment on vascular function in deoxycorticosterone acetate-salt hypertensive rats. Comparative study with verapamil. Planta Med. 2004, 70, 334-341. [PubMed]

41. Merendino, N.; Molinari, R.; Costantini, L.; Mazzucato, A.; Pucci, A.; Bonafaccia, F.; Esti, M.; Ceccantoni, B.; Papeschi, C.; Bonafaccia, G. A new "functional" pasta containing tartary buckwheat sprouts as an ingredient improves the oxidative status and normalizes some blood pressure parameters in spontaneously hypertensive rats. Food Funct. 2014, 5, 1017-1026. [CrossRef] [PubMed]

42. Monteiro, M.M.; Franca-Silva, M.S.; Alves, N.F.; Porpino, S.K.; Braga, V.A. Quercetin improves baroreflex sensitivity in spontaneously hypertensive rats. Molecules 2012, 17, 12997-13008. [CrossRef] [PubMed]

43. Ibarra, M.; Moreno, L.; Vera, R.; Cogolludo, A.; Duarte, J.; Tamargo, J.; Perez-Vizcaino, F. Effects of the flavonoid quercetin and its methylated metabolite isorhamnetin in isolated arteries from spontaneously hypertensive rats. Planta Med. 2003, 69, 995-1000. [PubMed]

44. Parichatikanond, W.; Pinthong, D.; Mangmool, S. Blockade of the renin-angiotensin system with delphinidin, cyanin, and quercetin. Planta Med. 2012, 78, 1626-1632. [CrossRef] [PubMed]

45. Olaleye, M.T.; Crown, O.O.; Akinmoladun, A.C.; Akindahunsi, A.A. Rutin and quercetin show greater efficacy than nifedipin in ameliorating hemodynamic, redox, and metabolite imbalances in sodium chloride-induced hypertensive rats. Hum. Exp. Toxicol. 2014, 33, 602-608. [CrossRef] [PubMed]

46. Geraets, L.; Moonen, H.J.; Brauers, K.; Wouters, E.F.; Bast, A.; Hageman, G.J. Dietary flavones and flavonoles are inhibitors of poly(ADP-ribose)polymerase-1 in pulmonary epithelial cells. J. Nutr. 2007, 137, 2190-2195. [PubMed]

47. Yang, D.; Liu, X.; Liu, M.; Chi, H.; Liu, J.; Han, H. Protective effects of quercetin and taraxasterol against $\mathrm{H}_{2} \mathrm{O}_{2}$-induced human umbilical vein endothelial cell injury in vitro. Exp. Ther. Med. 2015, 10, 1253-1260. [CrossRef] [PubMed]

48. Krol, W.; Czuba, Z.; Scheller, S.; Gabrys, J.; Grabiec, S.; Shani, J. Anti-oxidant property of ethanolic extract of propolis (EEP) as evaluated by inhibiting the chemiluminescence oxidation of luminol. Biochem. Int. 1990, 21, 593-597. [PubMed] 
49. Javadi, F.; Eghtesadi, S.; Ahmadzadeh, A.; Aryaeian, N.; Zabihiyeganeh, M.; Foroushani, A.R.; Jazayeri, S. The effect of quercetin on plasma oxidative status, C-reactive protein and blood pressure in women with rheumatoid arthritis. Int. J. Prev. Med. 2014, 5, 293-301. [PubMed]

50. Pfeuffer, M.; Auinger, A.; Bley, U.; Kraus-Stojanowic, I.; Laue, C.; Winkler, P.; Rufer, C.E.; Frank, J.; Bosch-Saadatmandi, C.; Rimbach, G.; et al. Effect of quercetin on traits of the metabolic syndrome, endothelial function and inflammation in men with different APOE isoforms. Nutr. Metab. Cardiovasc. Dis. 2013, 23, 403-409. [CrossRef] [PubMed]

51. Erdogan, A.; Most, A.K.; Wienecke, B.; Fehsecke, A.; Leckband, C.; Voss, R.; Grebe, M.T.; Tillmanns, H.; Schaefer, C.A.; Kuhlmann, C.R. Apigenin-induced nitric oxide production involves calcium-activated potassium channels and is responsible for antiangiogenic effects. J. Thromb. Haemost. 2007, 5, 1774-1781. [CrossRef] [PubMed]

52. Dayoub, O.; Andriantsitohaina, R.; Clere, N. Pleiotropic beneficial effects of epigallocatechin gallate, quercetin and delphinidin on cardiovascular diseases associated with endothelial dysfunction. Cardiovasc. Hematol. Agents Med. Chem. 2013, 11, 249-264. [CrossRef] [PubMed]

53. Galleano, M.; Pechanova, O.; Fraga, C.G. Hypertension, nitric oxide, oxidants, and dietary plant polyphenols. Curr. Pharm. Biotechnol. 2010, 11, 837-848. [CrossRef] [PubMed]

54. Formica, J.V.; Regelson, W. Review of the biology of Quercetin and related bioflavonoids. Food Chem. Toxicol. 1995, 33, 1061-1080. [CrossRef]

55. Bischoff, S.C. Quercetin: potentials in the prevention and therapy of disease. Curr. Opin. Clin. Nutr. Metab. Care 2008, 11, 733-740. [CrossRef] [PubMed]

56. Perez-Vizcaino, F.; Duarte, J. Flavonols and cardiovascular disease. Mol. Aspects Med. 2010, 31, 478-494. [CrossRef] [PubMed]

57. Seebaluck, R.; Gurib-Fakim, A.; Mahomoodally, F. Medicinal plants from the genus Acalypha (Euphorbiaceae)-a review of their ethnopharmacology and phytochemistry. J. Ethnopharmacol. 2015, 159, 137-157. [CrossRef] [PubMed]

58. Aoi, W.; Niisato, N.; Sawabe, Y.; Miyazaki, H.; Marunaka, Y. Aldosterone-induced abnormal regulation of ENaC and SGK1 in Dahl salt-sensitive rat. Biochem. Biophys. Res. Commun. 2006, 341, 376-381. [CrossRef] [PubMed]

59. Aoi, W.; Niisato, N.; Sawabe, Y.; Miyazaki, H.; Tokuda, S.; Nishio, K.; Yoshikawa, T.; Marunaka, Y. Abnormal expression of ENaC and SGK1 mRNA induced by dietary sodium in Dahl salt-sensitively hypertensive rats. Cell Biol. Int. 2007, 31, 1288-1291. [CrossRef] [PubMed]

60. Marunaka, Y.; Niisato, N.; Taruno, A.; Ohta, M.; Miyazaki, H.; Hosogi, S.; Nakajima, K.; Kusuzaki, K.; Ashihara, E.; Nishio, K.; et al. Regulation of epithelial sodium transport via epithelial $\mathrm{Na}^{+}$channel. J. Biomed. Biotechnol. 2011, 2011, 978196. [CrossRef] [PubMed]

61. Schweda, F. Salt feedback on the renin-angiotensin-aldosterone system. Pflugers Arch. 2015, 467, 565-576. [CrossRef] [PubMed]

62. Bollag, W.B. Regulation of aldosterone synthesis and secretion. Compr. Physiol. 2014, 4, 1017-1055. [PubMed]

63. Warnock, D.G.; Kusche-Vihrog, K.; Tarjus, A.; Sheng, S.; Oberleithner, H.; Kleyman, T.R.; Jaisser, F. Blood pressure and amiloride-sensitive sodium channels in vascular and renal cells. Nat. Rev. Nephrol. 2014, 10, 146-157. [CrossRef] [PubMed]

64. Canessa, C.M.; Horisberger, J.D.; Rossier, B.C. Epithelial sodium channel related to proteins involved in neurodegeneration. Nature 1993, 361, 467-470. [CrossRef] [PubMed]

65. Canessa, C.M.; Schild, L.; Buell, G.; Thorens, B.; Gautschi, I.; Horisberger, J.D.; Rossier, B.C. Amiloride-sensitive epithelial $\mathrm{Na}^{+}$channel is made of three homologous subunits. Nature 1994, 367, 463-467. [CrossRef] [PubMed]

66. Ji, H.L.; Zhao, R.Z.; Chen, Z.X.; Shetty, S.; Idell, S.; Matalon, S. delta ENaC: A novel divergent amiloride-inhibitable sodium channel. Am. J. Physiol. Lung Cell. Mol. Physiol. 2012, 303, L1013-L1026. [CrossRef] [PubMed]

67. Shimkets, R.A.; Warnock, D.G.; Bositis, C.M.; Nelson-Williams, C.; Hansson, J.H.; Schambelan, M.; Gill, J.R., Jr.; Ulick, S.; Milora, R.V.; Findling, J.W.; et al. Liddle's syndrome: heritable human hypertension caused by mutations in the $\beta$ subunit of the epithelial sodium channel. Cell 1994, 79, 407-414. [CrossRef] 
68. Snyder, P.M.; Price, M.P.; McDonald, F.J.; Adams, C.M.; Volk, K.A.; Zeiher, B.G.; Stokes, J.B.; Welsh, M.J. Mechanism by which Liddle's syndrome mutations increase activity of a human epithelial $\mathrm{Na}^{+}$channel. Cell 1995, 83, 969-978. [CrossRef]

69. Firsov, D.; Schild, L.; Gautschi, I.; Merillat, A.M.; Schneeberger, E.; Rossier, B.C. Cell surface expression of the epithelial Na channel and a mutant causing Liddle syndrome: A quantitative approach. Proc. Natl. Acad. Sci. USA 1996, 93, 15370-15375. [CrossRef] [PubMed]

70. Kamynina, E.; Debonneville, C.; Hirt, R.P.; Staub, O. Liddle's syndrome: A novel mouse Nedd4 isoform regulates the activity of the epithelial $\mathrm{Na}^{+}$channel. Kidney Int. 2001, 60, 466-471. [CrossRef] [PubMed]

71. Hanukoglu, I.; Hanukoglu, A. Epithelial sodium channel (ENaC) family: Phylogeny, structure-function, tissue distribution, and associated inherited diseases. Gene 2016, 579, 95-132. [CrossRef] [PubMed]

72. Rizzo, F.; Staub, O. NEDD4-2 and salt-sensitive hypertension. Curr. Opin. Nephrol. Hypertens. 2015, 24, 111-116. [CrossRef] [PubMed]

73. Ronzaud, C.; Staub, O. Ubiquitylation and control of renal $\mathrm{Na}^{+}$balance and blood pressure. Physiology (Bethesda) 2014, 29, 16-26. [CrossRef] [PubMed]

74. Yang, K.Q.; Xiao, Y.; Tian, T.; Gao, L.G.; Zhou, X.L. Molecular genetics of Liddle's syndrome. Clin. Chim. Acta 2014, 436, 202-206. [CrossRef] [PubMed]

75. Bubien, J.K. Epithelial $\mathrm{Na}^{+}$channel (ENaC), hormones, and hypertension. J. Biol. Chem. 2010, 285, 23527-23531. [CrossRef] [PubMed]

76. Marunaka, Y.; Marunaka, R.; Sun, H.; Yamamoto, T.; Kanamura, N.; Taruno, A. Na+ homeostasis by epithelial $\mathrm{Na}^{+}$channel $(\mathrm{ENaC})$ and $\mathrm{Na}_{\mathrm{x}}$ channel $\left(\mathrm{Na}_{\mathrm{x}}\right)$ : Cooperation of $\mathrm{ENaC}$ and $\mathrm{Na}_{\mathrm{x}}$. Ann. Transl. Med. 2016, 4, S11. [CrossRef] [PubMed]

77. Nakajima, K.I.; Marunaka, Y. Intracellular chloride ion concentration in differentiating neuronal cell and its role in growing neurite. Biochem. Biophys. Res. Commun. 2016, 479, 338-342. [CrossRef] [PubMed]

78. Cermak, R.; Follmer, U.; Wolffram, S. Dietary flavonol quercetin induces chloride secretion in rat colon. Am. J. Physiol. Gastrointest. Liver Physiol. 1998, 275, G1166-G1172.

79. Cermak, R.; Vujicic, Z.; Scharrer, E.; Wolfram, S. The impact of different flavonoid classes on colonic $\mathrm{Cl}^{-}$ secretion in rats. Biochem. Pharmacol. 2001, 62, 1145-1151. [CrossRef]

80. Asano, J.; Niisato, N.; Nakajima, K.; Miyazaki, H.; Yasuda, M.; Iwasaki, Y.; Hama, T.; Dejima, K.; Hisa, Y.; Marunaka, Y. Quercetin stimulates $\mathrm{Na}^{+} / \mathrm{K}^{+} / 2 \mathrm{Cl}^{-}$cotransport via PTK-dependent mechanisms in human airway epithelium. Am. J. Respir. Cell Mol. Biol. 2009, 41, 688-695. [CrossRef] [PubMed]

81. Sun, H.; Niisato, N.; Marunaka, Y. Quercetin diminishes the cAMP-stimulated $\mathrm{Cl}^{-}$secretion by blocking $\mathrm{Na}^{+}, \mathrm{K}^{+}$-ATPase in epithelial cells. J. Physiol. Sci. 2014, 64, S116.

82. Nguyen, T.D.; Canada, A.T.; Heintz, G.G.; Gettys, T.W.; Cohn, J.A. Stimulation of secretion by the T84 colonic epithelial cell line with dietary flavonols. Biochem. Pharmacol. 1991, 41, 1879-1886. [CrossRef] 